\title{
19.
}

\section{INTELEKTUALAC KAO NEGATIVNI \\ DIJALEKTIČAR: PARALELNO ČITANJE \\ ADORNA I KRLEŽE}

\section{Ivan Majić}

UDK: 821.163.42Krleža, M.:1Adorno, T.

Izvorni znanstveni članak

Sažetak: Članak je nastao kao rezultat paralelnog čitanja tekstova Theodora Adorna i Miroslava Krleže i to onih tekstova i onih dijelova koji se tiču problematike odnosa intelektualca i Drugoga svjetskog rata. Iako pišu u različitim diskurzivnim formacijama u kojima je suprotstavljen pretežno književno-esejistički i filozofski interes, ova dva autora, dijeleći zajedničko vrijeme djelovanja, kako u profesionalnim aktivnostima, tako donekle i u mišljenju, zadržavaju sličnu poziciju. U tom se smislu ključnom pokazuje kod obaju autora preokupacija odnosom prema prosvjetiteljskoj (europskoj) misli u kontekstu kreiranja duhovnog stanja presudnog za pojavu totalitarizma. Obojica, međutim, nastoje radikalno propitati posljedice do kojih je dovela ta misao „razularenog racionalizma”, zadržavajući pritom potrebu da se očuva pozicija mišljenja kao krajnje instance u kojoj intelektualac ima pravo na djelovanje.

Ključne riječi: intelektualac, Drugi svjetski rat, totalitarizam, kritička teorija, Theodor W. Adorno, Miroslav Krleža

\section{Pametni su svuda svojom glupošću barbarima olakšavali posao. („Dijalektika prosvjetiteljstva”) \\ Od sviju evropskih pojava najžalosnija je danas evropska pamet. („Evropa danas”)}

I.

ako se užas rata pojavljuje kao središnji motivski, sadržajni i kontekstualni aspekt u opusu Miroslava Krleže, ono što Krležu približava Adornovom pristupu, treba tražiti ne toliko u aktualizaciji kritike rata i prokazivanju ratne mašinerije mišljenja, koliko u pokušaju da se pronikne u apriornu ratnu pseudo-logiku čije provođenje rezultira stanjem u kojemu do rata nužno mora doći. I stoga ne iznenađuje svojevrsna anticipacija Drugoga svjetskog rata u poznatom eseju Evropa danas iz 1933. godine, u kojem Krleža, pored ostaloga, 
konstatira da „Evropa putuje u gvozdenom oklopljenom tenku, službeno uvjerena o svom božanskom podrijetlu, svake minute spremna da ponovo zakolje dvadeset milijuna svojih stanovnika", ${ }^{1}$ kao što ne iznenađuje ni učestalo povezivanje Drugoga svjetskog rata s Prvim svjetskim ratom u brojnim esejima u kojima se važnijom od faktične stvarnosti različitih objektivnih okolnosti pokazuje zajednička logika rata koja je uvijek ista „od Homera do Bonapartea" ${ }^{2}$. Ono što karakterizira (nefikcionalne) tekstove Adorna i Krleže, iako pišu u različitom diskurzivnom registru, za različitu publiku i u posve različitim sredinama, nalazi se u zajedničkoj preokupaciji i promišljanju uvjeta koji su omogućili pojavu fašizma (ili u Krležinom slučaju bilo kojeg oblika „nacionalističke propovijedi”)'). Drugim riječima, u tekstovima nastalim uoči, za vrijeme ili netom nakon Drugoga svjetskog rata, kao zajednički element kod obaju autora može se apstrahirati nastojanje da se adresiraju uzročnici prije svega idejno-svjetonazornih, a onda i misaonih zastranjenja koji rezultiraju političkim i etničkim progonima i eskalacijom nasilja.

Najkraće rečeno, i Adorno i Krleža, svaki na svoj način, problematiziraju ono krajnje stanje u kojem dolazi do dokinuća mišljenja, a gdje nasilje postaje opravdano navodnom činjenicom da su svi elementi mišljenja ,iscrpljeni”. I upravo točka u kojoj je nužnost nasilja očita, postaje polaznom točkom njihove analize koja za cilj ima problematizirati proces koji je toj krilatici o nužnosti nasilja i iscrpljenosti mišljenja prethodio te njome rezultirao. Krleža je tu u spomenutom eseju posebno lucidan budući da on ne odvaja mišljenje od samoga nasilja, odnosno, Krleži je stalo da ukaže na neodvojivost nasilja i mišljenja. Jednostavnije rečeno, umjesto da uspostavi „zdravorazumsku” dihotomiju „humanog” mišljenja i „barbarskog” nasilja, on „dijalektički” u mišljenju vidi nasilje, a u nasilju mišljenje te se njihova historijska izmjena pokazuje „dosadna kao odsvirana gramofonska ploča”. ${ }^{4} \mathrm{U}$ tom smislu, izmjena mišljenja i nasilja za Krležu je stara i dosadna, ali na neki groteskan način, ona je i nužna i formira upravo onu „istinu” Evrope koja se diči svojim visokim humanističkim dostignućima:

Tipična je evropska pojava, da su najveće evropske istine izgovorene ispod vješala, na stratištima, po tamnicama i na golgotama, a te raspete i popljuvane istine postaju evropske zastave i vijore se vjekovima. ${ }^{5}$

Pri tome nije od presudne važnosti činjenica da ta tenzija između mišljenja i nasilja u brojnim tekstovima ovih dvaju pisaca rezultira različitim vrijednosnim artikulacijama u rasponu od indignacije i rezignacije pa sve do apatičnog pesimizma ili čak literarnog bijesa. Upravo suprotno, metoda čitanja „društva” kojom se služe Krleža na jedan način i Adorno na drugi treba se uzeti doslovno i u čitanju njihovih tekstova, gdje nije toliko bitan sadržaj o kojemu je u tekstu riječ, koliko prethodni impuls koji je samo pisanje inicirao. Na tom se mjestu, dakle, prije pisanja, točnije u njegovom idejnom začetku, kako kod Krleže, tako i kod Adorna nalazi središnji problem. Središnja misaona tenzija sastoji se upravo u etičkom problemu samoga čina mišljenja, a etičnost je poljuljana činjenicom da se mišljenje i totalitarizam nakon Drugog svjetskog rata više ne mogu jasno odvojiti, prije će biti obratno, totalitarizam je mišljenjem

\footnotetext{
Miroslav KRLEŽA, Evropa danas, Sarajevo 1973., 23.-24.

Miroslav KRLEŽA, Eseji I, Sarajevo 1973., 179.

Isto, 186.

M. KRLEŽA, Evropa danas, 11.

Isto, 13.

Max HORKHEIMER - Theodor ADORNO, Dijalektika prosvjetiteljstva, Sarajevo 1974., 20.
} 
uvjetovan, a „prosvjetiteljska misao jest totalitarna”. ${ }^{6}$ Nadalje, ako je rat na dubljoj razini pripremljen aparatom intelektualnoga mišljenja koje preko filozofije, pjesništva i povijesti stvara atmosferu kulturnoga separatizma, a ne toliko povećanom proizvodnjom oružja i stvaranjem političkih napetosti (koje su posljedice, a ne uzroci ratnog stanja svijesti), što potpisuju i Krleža i Adorno u svojim esejima, tada se etičnost mišljenja sastoji od konzekventnog dovođenja pod znak pitanja baš intelektualnog mišljenja. Drugim riječima, ako je mišljenje zakazalo te u nekim svojim pojavnim oblicima ne samo da nije zaustavilo totalitarno ludilo, već ga je i potaklo, tada se ključno pitanje samo od sebe nameće: kako uopće misliti nakon rata, nakon holokausta, nakon pomora čovječanstva? Kako misliti ako je oruđe mišljenja već historijski okaljano jer se bilo svojom benevolentnošću spram fašizma, bilo svojim suučesništvom, bilo svojom nedjelotvornošću pokazalo etički spornim te funkcionalno nedostatnim?

\section{II.}

Ključni se pomak kojim Adorno i Krleža, svaki na svoj način, u svojim tekstovima suprotstavljaju mainstreamu posthitlerovskog vremena sastoji u činjenici da oni inzistiraju na analizi koja izbjegava podjelu na totalitarno, antisemitsko i fašističko $s$ jedne strane te liberalno, progresivno i socijalističko (ili kapitalističko) s druge, već se ne libe autokritičkim manevrom zapitati: nije li upravo liberalno, demokratsko, progresivno i evropsko intelektualno mišljenje, samom činjenicom da je fašizam uspio pobijediti, zakazalo? Kao ilustracija tomu, može poslužiti nekoliko citata. U spomenutom eseju Evropa danas Krleža je eksplicitan:

(...) dok se u mozgovima evropskim kao u alkemijskim pivnicama kuhaju osnovna neriješena pitanja o odnosima subjekta i objekta, o apsolutnom i relativnom, dotle se evropski narodi igraju svojim olovnim igračkama ratova, i ta djetinjasta halabuka traje u Evropi neprekidno već sedamdeset hiljada godina. ${ }^{7}$

Adorno s druge strane, u koautorstvu s Horkheimerom u znamenitoj Dijalektici prosvjetiteljstva potpuno otvoreno u predgovoru knjige u filozofskoj misli vidi potencijalnog neprijatelja jer: „ukoliko trijumfirajuća misao vlastitom voljom napusti kritički element i postane pukim sredstvom u službi postojećega, ona protiv svoje volje ono pozitivno što je izabrala pretvara u negativno, razarajuće". ${ }^{8}$ Nadalje, posve deklamativno:

Nipošto ne sumnjamo - a u tome jest naša petitio principii - da se sloboda u društvu ne može odvojiti od prosvijećenog mišljenja. Ali, ujedno mislimo da smo podjednako razgovjetno spoznali kako je već u samom pojmu ovog mišljenja, a ne samo u konkretnim historijskim formama, društvenim institucijama u koje je zapleteno, sadržana klica onog nazadovanja do kojeg danas dolazi. ${ }^{9}$

Brojni su citati kojima se može oprimjeriti ova inicijalna kritička pozicija kod Adorna i Krleže. Međutim, spomenuti problem ni za Krležu ni za Adorna nije ni blizu razrješenja

M. KRLEŽA, Evropa danas, 16.

M. HORKHEIMER - T. ADORNO, Dijalektika prosvjetiteljstva, 8.

Isto, 9. 


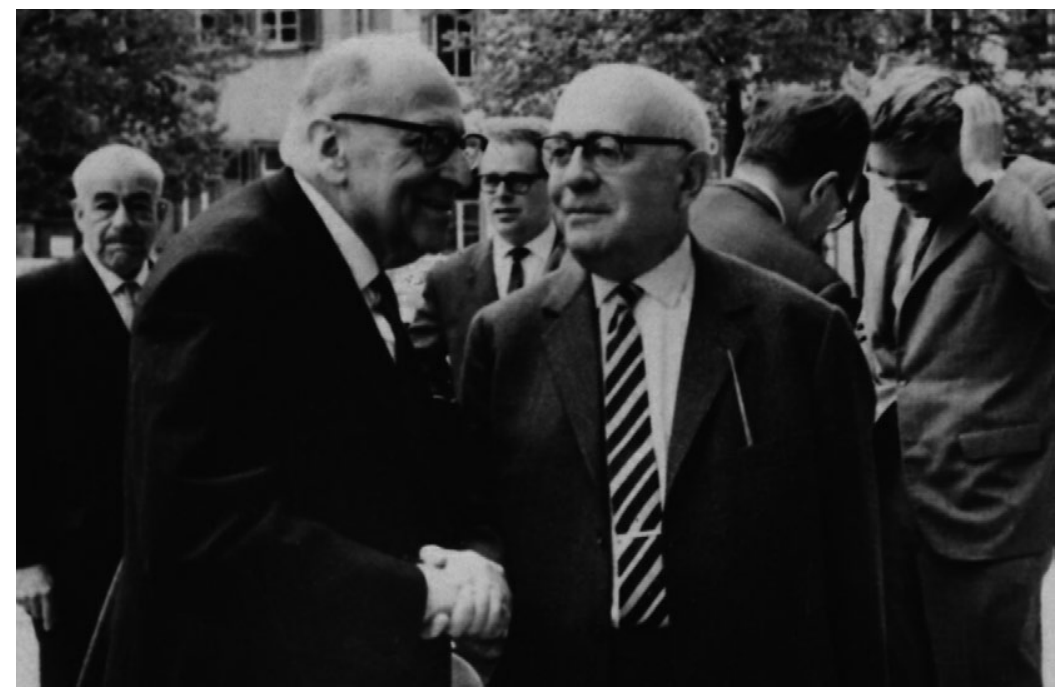

Slika 1. Theodor Adorno (desno) i Max Horkheimer (lijevo) 1965. godine u Heidelbergu

budući da se paralelno s njihovom ustrajnom strategijom pisanja o problemima liberalizma, prosvjetiteljstva i dominantne filozofske i kulturne matrice poslijeratnog vremena, problem vlastitog pozicioniranja unutar kulturne paradigme još uvijek nalazi kao etički imperativ u središtu njihova intelektualnog djelovanja. Jednostavnije rečeno, prokazivati probleme prosvjetiteljstva, čija je totalitarna logika ovladavanja čovjeka nad prirodom dovela do potpune besubjektivacije subjekata (Adorno), naposljetku nije ništa drugo nego još jedan prosvjetiteljski manevar višega reda. Ili, u Krležinu slučaju, na poznatom primjeru iz eseja o Erazmu Roterdamskom, osuđivati „klerikalnobanalnu, kurijalnoučtivu, pretvorljivu i potpuno negativnu" ${ }^{10}$ recenziju povodom mađarskog prijevoda Erazmove Pohvale gluposti ne jamči nužno biti izuzet od zahtjeva koji se pred Krležu postavlja, a to je, sažeto rečeno, odgovoriti na zahtjev koji si i sam Krleža postavlja: kako biti Erazmo danas? Stoga se pozicija s koje progovaraju i Adorno i Krleža neovisno o sadržaju i smjeru kritika kojima raskrinkavaju kulturnu industriju pokazuje izuzetno važnom jer ona dosljednost kojom se pristupa problemu kritike mišljenja svoj prvi test ima upravo u manifestaciji njihove vlastite pozicije intelektualca u poslijeratnom vremenu.

Toga su i Adorno i Krleža itekako svjesni. I dok Krleža taj procjep rješava preuzimajući ulogu državnog intelektualca u nadolazećim godinama, ne napuštajući svoje prosvjetiteljsko poslanje, a koje se do kraja manifestira u pokretanju Enciklopedije Jugoslavije i radu u Leksikografskom zavodu, kod Adorna se taj procjep kontinuirano iz djela u djelo perpetuira i obogaćuje novim misaonim rješenjima. U tom smislu, parafrazirajući podnaslov knjige Minima moralia, Adornova misao počinje funkcionirati poput neprekinute „refleksije iz oštećenoga života”. Oštećenost postaje ono središnje toga procjepa i Adorno kao filozofesejist kao da bez te oštećenosti više ne želi da piše. Jer, ako želi biti dosljedan u provođenju kritike misli (pri čemu je prosvjetiteljska, građanska misao posebno bivala sporna u svojoj totalnosti, a time i totalitarnosti omogućivši fašizam), tada se svako mišljenje koje slijedi

${ }_{10}$ M. KRLEŽA, Eseji I, 141. 


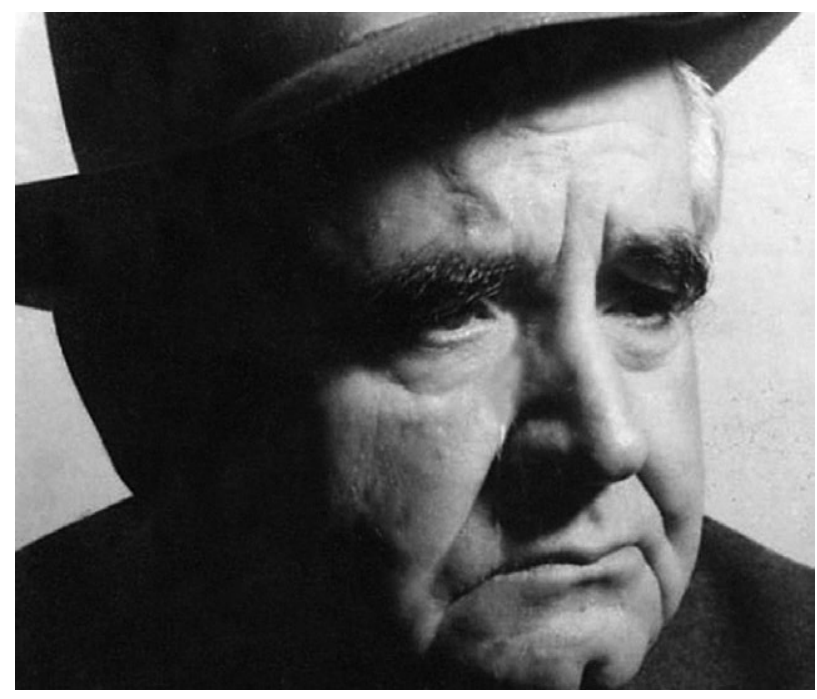

Slika 2. Miroslav Krleža

nakon fašizma mora legitimirati upravo kroz onu oštećenost i onaj zazor kojim se ono nastoji s jedne strane odvojiti od jednosmjerne totalitarne, prosvjetiteljske misli, a s druge, figurativno rečeno „priznati grijeh” nemoći iz prošlosti, one nemoći misli uz koju je fašizam uspio prevladati. U tom smislu, Adorno odbija mogućnost da se „stanje prividno normalizira”, „kao da se fašizam nije dogodio”:

Misao da bi nakon ovog rata život mogao da „normalno” teče dalje, ili da čak kultura bude „ponovno izgrađena” - kao da sama ponovna izgradnja kulture nije već njena negacija - je idiotska. ${ }^{11}$

Normalnost je za Adorna problem jer je već koncept normalnoga posljedica prosvijećenoga mišljenja koje će nakon prvog stupnja društvenog zaposjedanja prirode, tražiti „prirodnu” eliminaciju svega što se kosi sa samoproglašenom normalnosti koja nije ništa drugo nego ludilo i prisila nametnutoga, totalitarnoga mišljenja. Adorno će u jednom trenutku znakovito napisati: „kad bi bilo moguće nešto poput psihoanalize, (...) onda bi jedno takvo istraživanje moralo jasno utvrditi da se suvremena bolest sastoji upravo u normalnom."12

Jedna od najzanimljivijih i najizazovnijih Adornovih studija svakako je Negativna dijalektika (1966.). U njoj također odzvanja ta ista klopka u kojoj se mišljenje nalazi u sprezi $s$ totalitarizmom, a Hegelova se dijalektika pokušava preispitati i promisliti na podlozi kritike identičnosti koju ona posredno podrazumijeva. Na tom se mjestu Adorno jasno distancira od Hegelove pozicije, ali on se i kao filozof i intelektualac posthitlerovskog vremena ne libi kritički pozicionirati vlastitu misao u negativnom određenju, podrazumijevajući bilo kakvu pozitivnost ideološki spornom, implicitno prosvjetiteljskom te time totalitarnom:

\footnotetext{
11 Theodor ADORNO, Minima moralia; refleksije iz oštećenoga života, Sremski Karlovci - Novi Sad 2002., 60.

12 Isto, 63.
} 
Filozofija ne može dospjeti ni do čega pozitivnog što bi bilo identično s njezinom konstrukcijom. U procesu demitologiziranja pozitivnost se mora negirati sve do duboko unutar instrumentalnog uma, koji brine o demitologiziranju. Ideja pomirenja ne dopušta pozitivno postavljanje u pojmu. ${ }^{13}$

Adornova „negativna dijalektika” prema njegovim vlastitim riječima nije spojiva s Hegelovom prije svega jer

(d)ijalektika kao postupak znači da se misli u proturječnostima zbog jednog s obzirom na stvar doživljenog proturječja i protiv njega. (...) Njezino kretanje ne tendira identičnosti u diferenciji svakog predmeta od svog pojma; identičnost joj je dapače sumnjiva. Njena logika je logika raspadanja (...) identičnost tih pojmova sa subjektom je neistina. ${ }^{14}$

Promotri li se Adornova misao u svjetlu vremena u kojem je ona nastajala, vremenu iskustva totalitarizma Drugoga svjetskog rata, tada se teško oteti dojmu da je ona direktno $s$ tim vremenom povezana, i to determinirana negativnim prefiksima. Adorno kao da je u svom radu kontinuirano nastojao nadići problem mišljenja i totalitarizma, nikada ne prestajući jedno povezivati s drugim. Stoga je i etička pozicija koju je odlučio zauzeti postala pozicija „negativnog dijalektičara” s ciljem da ne prestane ukazivati na ideološko suučesništvo dijalektike, filozofije, pozitivnosti, identičnosti, pojma i subjekta (dijelom i kao pojmova prosvjetiteljske misli) s užasom totalitarizma koji je uslijedio. Stoga je pitanje „kako je moguće misliti nakon Drugoga svjetskoga rata” i za Adorna, kao i za Krležu, obilježeno implicitno pozitivnim odgovorom eksplicirane negativne misli, odnosno, mišljenjem koje institucionalno ne napušta poziciju intelektualca (Adorno-profesor filozofije, Krleža-ravnatelj Leksikografskog zavoda i pisac), ali mišljenjem koje s te pozicije ustrajava na negativnoj (ili točnije, kritičkoj) dijagnozi stanja misli. U tom smislu, Adornova negativna dijalektika, negiranje pozitivnosti, rad na demitologizaciji, neidentičnost pojma i subjekta, logika raspadanja, oštećenost kao preduvjet mišljenja na neki su način simptomi one greške koja je dovela do totalitarnog ludila, a mišljenje „nakon” kao da u sebi mora sadržavati etičko pozivanje na taj simptom kako bolest ponovno ne bi buknula. Postavlja se međutim pitanje, zaoštreno govoreći, mora li mišljenje nakon Drugog svjetskog rata biti mišljenje melankolički indigniranog bolesnika koji u negativnim demarkacijama okajava grijehe svojih prethodnika?

\section{III.}

Odgovor bi se na postavljeno zaoštreno pitanje iz prethodnog poglavlja u jednom drugom kontekstu zapravo mogao ticati dvojbe između mišljenja i djelovanja. Jer, misliti a pritom ustrajavati na etičkom nasljedovanju krivnje do koje je prosvjetiteljsko mišljenje dovelo, u sebi ima paradoksalan manevar mišljenja koje se onemogućuje ili drugim riječima, mišljenja koje onemogućuje svoj učinak (u djelovanju). Međutim, posrijedi je zapravo izbjegavanje iracionalnog (totalitarnog) učinka racionalne misli, a u tom se izbjegavanju misao stavlja u pulsirajuće stanje

\footnotetext{
13 Theodor ADORNO, Negativna dijalektika, Beograd 1979., 130.-131.

14 Isto.
} 
samo-onemogućavanja koje bi moglo rezultirati (ideološki) još opasnijim stanjem status quo. Da bi izbjegli taj melankolični status quo, i Krleža i Adorno pribjegavaju različitim postupcima, ali pritom nikada ne napuštaju „polje borbe”. Obojica ustrajavaju na „kritici ideologije”. Adorno nakon što znakovito napominje da "se treba urazumiti protiv svojeg uma”'15 (u čemu odzvanja prethodna kritika prosvjetiteljskog mišljenja i mišljenja koje svjesno radi protiv onih aspekata koji ga omogućuvaju, a sve kako bi se izbjegao novi totalitarizam), naglašava da „kritika ideologije nije nešto periferno, nešto unutar-znanstveno, nije ograničena na objektivni duh i proizvode subjektivno-ograničenog, nego je filozofijski centralna: kritika same konstitutivne svijesti." ${ }^{\prime 6}$ Adorno smatra da „snaga svijesti dostiže svoju vlastitu prijevaru” onda „kada se uoči razularena racionalnost, koja je pobjegla samoj sebi pritom postajući mitologijom”." ${ }^{7}$

Stoga put kojim Adorno bira ići i kao intelektualac i kao filozof-pisac je jasan, čak naslovno jasan: nakon „dijalektike prosvjetiteljstva” iz koje odzvanjaju rečenice kao što su: „Budući, međutim, da do realne emancipacije ljudi nije došlo ujedno s prosvjetljivanjem duha, sama naobrazba je oboljela” 18 ili „Nije antisemitski tek antisemitski program, nego programski mentalitet uopće” ${ }^{\prime 19}$ te „dijalektika prosvjetiteljstva objektivno prelazi u ludilo, a ludilo je ujedno ludilo njene političke realnosti”, ${ }^{20}$ Adorno smjelo kreće putem „negativne dijalektike”, koncepta i knjige čija je jedna od namjera „razvijanje njezinog paradoksalnog naslova". ${ }^{21}$ Ta filozofska knjiga u tipično Adornovom manevru u uvodu sadrži i sljedeću rečenicu koja osvjetljava procjep između čina mišljenja te (okaljane filozofske) pozicije s koje se misli:

Nakon što je filozofija prekršila obećanje po kojem je sjedinjena sa zbiljom ili će do toga sjedinjavanja uskoro doći, prinuđena je da bezobzirno kritizira samu sebe. ${ }^{22}$

Upravo intenzitet kojim Adorno pristupa problemu mišljenja u „oštećenom vremenu” jasan je pokazatelj da će on tijekom svoga djelovanja nastojati ne odvajati svoju misao od svojih postupaka, odnosno, da će svoju poziciju intelektualca kontinuirano propitivati, pa čak i onda kada 1969. neće stati na studentsku stranu tijekom studentskog pokreta. U tom smislu, Adornov tvrdokoran stav da zauzme do kraja poziciju profesora - intelektualca i okoristi se svim privilegijama koje s tim idu na neki način sličan je Krležinom intelektualnom i političkom pozicioniranju nakon rata.

Umjesto jednostavnog i brzog kritiziranja njihovih pozicija, a preispitujući njihovu dosljednost u misli i djelovanju, može se doći do zaključka koji je Marcuse, govoreći o Adornu, formulirao na sljedeći način:

Mislim da ne postoji nitko tko je toliko radikalno suprotstavljen postojećem društvu kao što je to bio Adorno, tko ga toliko radikalno poznaje i spoznaje. Njegovo je mišljenje bilo toliko beskompromisno da je sebi mogao priuštiti čak i uspjeh u tom društvu; taj uspjeh nije ni na kakav način inficirao njegovo mišljenje niti ga na bilo koji način kompromitirao. ${ }^{23}$

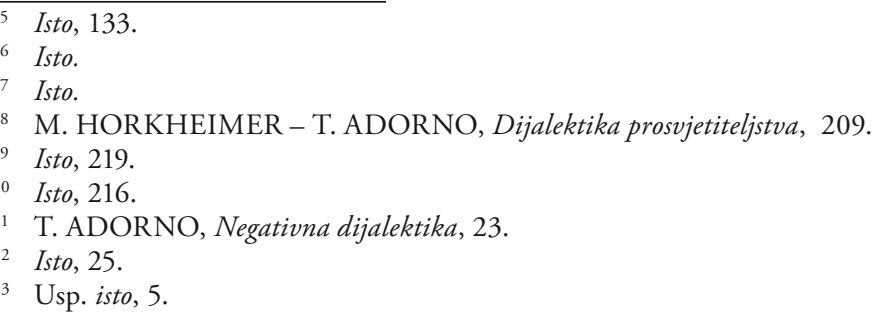


U Krležinom slučaju, poznata je i u esejima jasno istaknuta intelektualna ozbiljnost kojom on promatra kulturnu situaciju, a istom ozbiljnošću očekuje da se prosuđuje i njegov rad. U eseju $O$ našoj inteligenciji stoji:

Jedna je stvar biti primaš ciganski i guditi slatko uz dlakave uši pijandura, a drugo je pisati ozbiljno i mrko kao što se piše na zelenom stolu tribunala, gdje je sve tiho i mrtvački neutralno. A bude li tko pisao o nama kao takvima, on treba da piše mrko, okrutno i neumoljivo! ${ }^{24}$

Iza ovakvih citata zapravo stoji svijest o intelektualcu kojemu je primarna dužnost promatranje društva te jasna i kritički nedvosmislena dijagnoza pojava koje utječu na društvenu dinamiku odnosa.

Kod Adorna se takva nedvosmislena dijagnoza najjasnije vidi kada u svojim tekstovima eksplicitno adresira upravo civilizaciju i prosvjetiteljskog intelektualca kao ključ problema. Štoviše, u Dijalektici prosvjetiteljstva mogu se naći neočekivano oštre rečenice koje se tiču Židova, u kojima Horkheimer i Adorno pokazuju da se ne libe dublje ući u genezu antisemitizma. Citati koji slijede to najbolje ilustriraju:

Civilizacija je pobjeda društva nad prirodom koja sve pretvara u puku prirodu. Židovi su sami tisućljećima sudjelovali u tomu, i cinizmom i prosvjetiteljstvom. Budući da su najstariji preživjeli patrijarhat, inkarnaciju monoteizma, oni su tabue promijenili u civilizacijske maksime kada su drugi još ostajali kod magije. (...) Mehanizam kojim se služi totalitarni poredak star je kao i civilizacija. (...) U stanovitom je smislu svako zapažanje projiciranje. ${ }^{25}$

Izlazak iz tog škripca u kojemu su, jednostavno rečeno, „svi krivi” i to po pravilu: oni koji misle da su najneviniji (najčešće kulturni radnici), oni su najsumnjiviji jer su sudjelovali u kreiranju totalitarne kulturne industrije, Adorno vidi, pored ostaloga, upravo u djelovanju novog tipa filozofa, intelektualca za kojega „nije ništa neprimjerenije nego da u diskusiji, i čak bi se moglo reći vođenju dokaza, hoće da ima pravo. Htjeti biti u pravu predstavlja izraz onoga duha samoodržavanja čije razrješavanje zapravo čini ono do čega je filozofiji stalo." ${ }^{26}$ I još:

Kad se filozofi upuste u razgovor, a poznato je da im je ćutanje oduvijek padalo teško, onda bi trebalo da govore tako da oni svaki put ne zadrže pravo, ali na način koji protivnicima dokazuje neistinu.(...) Misliti dijalektički znači, u ovom aspektu, da argument treba dobiti drastiku teze, a teza da sadrži u sebi puninu svog razloga. ${ }^{27}$

I upravo je ta naoko nemoguća te istovremeno negativna pozicija ono što, i prema Adornu i prema Krleži, intelektualca čini djelatnim subjektom u kritici društva. Ustrajavanje na paradoksu, pogotovo onda kada paradoks zahvaća poziciju s koje se misli. Jer misao postaje djelatna jedino ako ima moć samopropitivanja, ako ulazi u genezu vlastite ideologije koja ju je ustoličila. Budući da je „cjelina neistina” (Negativna dijalektika), tada je jedini rad koji je intelektualcu kritičke teorije preostao onaj koji nastoji ukazivati na prešućene ideološke pretpostavke svakog mišljenja polazeći dakako, najprije od svoga vlastitoga. Tu je „gest in-

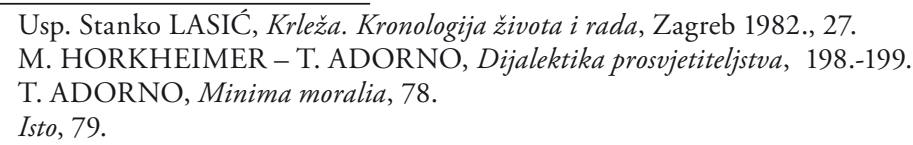


telektualca sličan onomu Münchhausena koji sebe iz močvare vuče za čuperak”. Adorno $s$ tom usporedbom ne može biti eksplicitniji, a njegov iskaz „od onog tko danas misli ne zahtijeva se ništa manje do da u svakom trenutku treba da bude u stvari i izvan stvari" ${ }^{28}$ na određeni način progovora i o načinu kako je Krleža svoju poziciju intelektualca realizirao.

\section{IV.}

Međutim, iz dijela prethodnih citata i dalje ostaje nešto u paradoksu što poziva na analitičko propitivanje. Na kraju krajeva, poslušamo li Krležin savjet da, pišemo li o njemu (i njemu sličnima), pišemo „mrko, okrutno i neumoljivo”, tada se neumoljivost pisanja o njemu neće očitovati u konstataciji kako je riječ o „intelektualcu svoga vremena”, već prije u ponešto „okrutnijoj i mrkijoj” kritici one ideološke pozicije koju je Krleža (a vidjet će se u nastavku i Adorno) prešutno zauzeo. Zaoštreno govoreći, ako u „diskusiji ništa nije neprimjerenije od toga da intelektualac hoće da bude u pravu", postavlja se pitanje alternative: kako govoriti (ozbiljno, mrko i neumoljivo), a da se ne nastoji da se bude u pravu? Koju poruku intelektualac šalje ako uistinu govori ne želeći zadržavati poziciju bivanja u pravu? Ako netko ne želi imati pravo/biti u pravu, tada on svakako nastoji osloboditi poziciju djelatne ovlasti koja omogućuje intelektualca da govori. Međutim, nije li tada odustajanje od pozicije „bivanja u pravu” krajnja (i ponovno melankolična) posljedica kritičke teorije koja odriče samoj sebi onu odgovornost koju intelektualno mišljenje zahtijeva? Nije li time, posredno, kritička misao sama uskliknula da se nalazi u krizi te da je bolje zašutjeti, nego kritički govoriti? Još i više, središnji problem kritike „intelektualca koji hoće da bude u pravu" ne nalazi se u melankoliji, pluralnosti ili liberalizaciji govora, već u mnogo dalekosežnijem odustajanju od „prava u govoru”. Drugačije rečeno, ne htjeti biti u pravu znači odustati od intencije na koju je govor navezan, znači lišiti govor onoga prava koji ga čini djelatnim. To je radikalan slijed kojega su, rekao bih, Krleža i Adorno na negativan način svjesni. Na negativan jer svojim djelovanjem nastoje činiti sve kako bi izbjegli tu stranputicu koja je prethodno dovela do totalitarnoga mišljenja od kojega se obojica žele što jasnije distancirati.

Najeklatantniji dokazi toga izbjegavanja mogu se vidjeti uoči li se intenzitet s kojim i Krleža i Adorno nastoje paradoksalno upravo zadržati poziciju intelektualca koji ima pravo na riječ. Kao da se u pozadini toga pozivanja na govor koji ne pretendira da se mora biti u pravu to pravo tim odstupanjem na neki način zadobiva, kao da rečenica „ne nastojim biti u pravu" etički opravdava poziciju s koje se govori, kao da se sam govor koji slijedi time legitimira (po logici dvostruke negacije) kao govor koji ne može ne biti u pravu. Iz te se dvostruke negacije oslobađa jasna potreba da se zadrži pozitivna pozicija intelektualca koji ima pravo na riječ (ono pravo koje je potvrđeno upravo time što se voljno odstupilo od njega). Jer, kako osigurati etičku poziciju (i posao) intelektualca ako ga se prethodno razvlasti i optuži da ga je obuzela „razularena racionalnost” koja ga je dovela do totalitarizma, ako ne kroz negativno ustoličavanje dvostrukog razvlašćivanja koje ga „čisti” i priprema za novi uzlet mišljenja „novog” intelektualca koji u sebi nikada neće napustiti legitimacijsko samoodstupanje od "prava da se bude u pravu”. 
„Okrutnije” rečeno, radi se o retoričkom manevru koji i Adornu i Krleži osigurava s jedne strane prostor za intelektualno djelovanje koje će biti lišeno pozivanja na „grijehe otaca”, ali, što je bitnije, koje će tom negativnom logikom, zadržati nešto od onoga prava koje je intelektualno mišljenje fatalnom pogreškom totalitarizma izgubilo. To pravo dakako, ne smije biti ništa drugo do negacija prava na bivanje u pravu koje je dovelo do razularene racionalnosti totalitarizma. Tek negacijom, po Adornu i Krleži (dakako uz brojne različitosti i varijacije među njihovim raznorodnim tekstovima), to pravo ponovno biva stečeno.

U pozadini se toga retoričkoga manevra, mišljenja sam, nalazi i središte problema koji se očituje u naizgled iznenađujućem odnosu Adorna i Krleže kao teoretičara i kao „djelatnih intelektualaca". Obojica kao da konzervativno ustrajavaju na institucionalnoj poziciji intelektualca (Krleža kao direktor Leksikografskog zavoda, a Adorno kao redoviti profesor koji uslijed studentske pobune 1969. poziva policiju da osigura red potreban za održavanje predavanja) dok je njihov misaoni rad nedvojbeno vezan uz radikalnu kritiku „prosvjetiteljskoga intelektualca” te nude mogućnosti za alternativnu kritičku misao. Ovdje je nužno naglasiti da se Adorno u najvećoj mjeri oslanja na tradiciju frankfurtske škole kritičkog mišljenja kojoj je filozofija modus operandi dok je Krleža, pored ostaloga, književnik, esejist, romanopisac, dramatičar, esejist i pjesnik te njihovo shvaćanje diskurzivnog okvira vlastita djelovanja nipošto nije isto. Međutim, kada je u središtu analize intelektualac kao subjekt djelovanja i mišljenja, tada obojica upadaju, kako je nerijetko kritika i ukazala, u sličan procjep konzervativnih intelektualaca kritičke misli. Posrijedi je upravo odnos između teorije i prakse, odnosno, dijalektičkog odnosa u kojem se jedno drugim omogućuje i onemogućuje. Upravo je to u središtu prijepora između Marcusea i Adorna kada u prepisci Marcuse Adornu prigovara pozivanje policije videći u studentskom pokretu onu „praksu koja teoriju pokreće”, dok Adorno na tu opasku reagira sljedećim riječima: „Priznao bih ti da postoje trenuci u kojima je teorija praksom pogurnuta dalje, ali niti danas takva situacija prevladava, niti usamljeni i brutalni prakticizam, s kojim smo ovdje suočeni, $s$ teorijom ima ikakve veze" ${ }^{29}$ i dalje, za ovu raspravu još važnije Adorno Marcuseu piše:

Ti smatraš da praksa danas, u emfatičnome smislu, nije nedostupna: ja mislim drugačije. Morao bih zanemariti sve što sam mislio i što znam o objektivnoj tendenciji kada bih htio vjerovati da studentski pokret u Njemačkoj ima i najmanji izgled za društveni učinak. Budući da on to nema, njegov je učinak upitan u dvostrukom smislu. Prvo, u smislu toga da on potpaljuje nesmanjeni fašistički potencijal u Njemačkoj, a da za to ni najmanje ne mari; drugo, tako što u sebi samome stvara tendencije koje - i tu se također smijemo razilaziti $s$ fašizmom neposredno konvergiraju. $U$ tome pogledu simptomatičnim smatram tehniku pozivanja na diskusiju samo kako bi se ona učinila nemogućom; barbarska neljudskost načina ponašanja koji je regresivan i koji još k tomu regresiju zamjenjuje revolucijom; slijepi primat akcije; formalizam koji je indiferentan spram sadržaja i oblika toga protiv čega se buni, naime naše teorije. ${ }^{30}$

Ubrzo nakon spomenutog citata Adorno uspoređuje da se „ordinarijus” kao redoviti profesor, „sasvim slično, ponizno, ali 'odozgo”” počelo koristiti kao riječ Židov u nacizmu. Iz svega se toga vidi da Adorno na poziciju intelektualca gleda na jedan kompleksan, ali dosljedan način. Naime, svaki oblik mišljenja najprije mora proći test u kojem se očituje

29 Theodor ADORNO - Herbert MARCUSE, „Prepiska o studentskom pokretu”, Čemu, 10/2011., br. 20, 83.

30 Isto, 88. 
njegova implicitna totalitarnost. Ako „tehnika pozivanja na diskusiju služi samo tome da se ista onemogući”, tada je diskusija lažna, totalitarna. Međutim, teorija služi tomu da se osigura „polje prava na diskusiju” i institucionalno brisanje toga Adorno shvaća „u posve prosvjetiteljskom smislu”, a pozivajući policiju i sam pribjegava „slijepom primatu akcije”. Drugim riječima, Adornova misao koja ustrajava na „odustajanju od prava da se bude u pravu” podrazumijeva prostor diskusije gdje nitko ne mora biti u pravu, a time se pravo na riječ dobiva. Međutim, ako se to pravo izgubi na način da „ne biti u pravu” znači izgubiti „pravo na riječ", tada je Adorno svjestan da je posrijedi totalitarizam višega i opasnijega reda.

Slično je s Krležom. Sve dok se misao koja nastoji izgraditi svoju vlastitu dinamiku sudara s udarcima bubnjeva, problem nije u „odnosima subjekta i objekta, apsolutnom i relativnom”. Problem je u olovnim igračkama koje čekaju da se ta misao dokine. Stoga je i pozicija intelektualca da neprestano ukazuje da je, pored misli koja sebi pribavlja pravo na egzistenciju dokazujući se anti-totalitarnom, problem veći u „udarima evropskih vojničkih truba koje odzvanjaju ozbiljnim i dostojanstvenim tišinama današnje evropske misli." ${ }^{11} \mathrm{Ni}$ Adorno ni Krleža ne zaboravljaju suučesništvo evropske prosvjetiteljske misli u kreiranju jedne, monolitne i totalitarne istine koja je dovela do užasa nacizma, ali obojica ustrajavaju na poziciji s koje se može misliti ne-identično, poziciji na kojoj se i „može ne biti u pravu”, ali se ta pozicija nipošto ne smije prepustiti „slijepom primatu akcije”. Naime, iza pozicije mišljenja nalazi se odgovornost intelektualca koji tu odgovornost očituje u sprečavanju dokinuća misli jer bi ono moglo dovesti do totalitarizma još većih i pogubnijih razmjera.

\section{$\cos$}

\section{The intellectual as a Negative dialectitian: A PARALlEL REAding OF AdORNO AND KRLEŽA}

The period immediately following World War II was, to a great extent, marked by the re-examination of the position of the intellectual. It manifested itself through the question "what made totalitarianism possible?" In other words, the key ethical question was that of responsibility for the circumstances conducive to the undeterred growth of Nazism. Although avoiding the blame represented the easier answer to that question, two entirely different intellectuals from very dissimilar milieus took another route and attempted to find responsibility within the humanist tradition itself. Those two intellectuals were Theodor W. Adorno and Miroslav Krleža. The former established his critical diagnosis towards the end of the war, alongside M. Horkheimer, in the Dialectic of Enlightenment, whereas the latter, in numerous essays, referred to a "logic of stupidity", which was inherent to European thought and mostly benevolent towards rising nationalisms. Although one was a philosopher and the other a writer, both Adorno and Krleža attempted to answer the same question: how to think and act after Nazism? Adorno adopted a theoretical approach which insisted on the necessity of preserving the position of "thinking about the non-identical" and developing a "negative dialectics" within which equating the subject and the concept (in a manner 
typical of totalitarianism) should be avoided. Krleža, on the other hand, considered ways to escape the machine of nationalist sermons which replaces the word with a military drum as the only element of value. At the backdrop of these intellectual strivings, institutional challenges emerged. In Adorno's case, they were connected to the Institute for Social Research and in Krleža's, with the Institute of Lexicography. Both men tried to support those institutions and, despite being critical, chose to defend the position of the intellectual. Although they both took issue with the very concept of the intellectual as defined by the Enlightenment, abandoning it was not an option because its institutional abolishment meant the threat of a much more radical kind of totalitarianism.

Keywords: the intellectual, World War II, totalitarianism, critical theory, Theodor W Adorno, Miroslav Krleža

\section{$\cos$}

\section{Literatura}

Theodor ADORNO, Minima moralia: refleksije iz oštećenoga života, Sremski Karlovci - Novi Sad 2002.

Theodor ADORNO, Negativna dijalektika, Beograd 1979.

Theodor ADORNO, Gesellschaftstheorie und Kulturkritik, Frankfurt am Main 1975.

Theodor ADORNO - Herbert MARCUSE, „Prepiska o studentskom pokretu”, Čemu, 10/2011., br. 20, 78.-93.

Max HORKHEIMER - Theodor ADORNO, Dijalektika prosvjetiteljstva, Sarajevo 1974.

Miroslav KRLEŽA, Dnevnik 1943, Sarajevo - Zagreb 1977.

Miroslav KRLEŽA, Eseji I, Sarajevo 1973.

Miroslav KRLEŽA, Eseji II, Sarajevo 1973.

Miroslav KRLEŽA, Evropa danas, Sarajevo 1973.

Stanko LASIĆ, Krleža. Kronologija života i rada, Zagreb 1982. 